\title{
LOCAL COMMUNITY AND ITS EXISTENCE: THE ENVIRONMENTAL WISDOM OF KASEPUHAN COMMUNITY AT KAMPONG CENGKUK, SUKABUMI DISTRICT, WEST JAVA
}

\author{
Ary Sulistyo \\ Program Studi Manajemen Perhotelan dan Pariwisata \\ Fakultas Bisnis dan Ilmu Sosial, International University Liaison Indonesia \\ ary.sulistyo@iuli.ac.id
}

\begin{abstract}
ABSTRAK
Penelitian ini membahas tentang kelestarian lingkungan pada kampung adat Sunda kawasan Gunung Halimun Selatan. Kampung adat Cengkuk adalah salah satu kampung pengikut yang mengikuti tradisi atau Kasepuhan Ciptagelar dalam pengelolaan lingkungan. Faktor dari dalam dan luar kampung menyebabkan deforestasi hutan alam rata-rata sekitar 6-8\% per tahun. Pertambahan penduduk kampung mencapai rata-rata $5,35 \%$ per tahun dikategorikan sangat padat. Dengan pendekatan deskriptif kualitatif dan wawancara, menunjukkan bahwa tradisi atau adat Kasepuhan masih dianut warga kampung dengan menjaga hutan tutupan (leuweung tutupan) di sebelah selatan Kampung hanya untuk kegiatan subsistensi. Perubahan sosio-kultur terjadi pada masyarakat dengan tidak melakukan kegiatan berladang di hutan (outer island agriculture) tetapi lebih kepada kegiatan bertani di sawah (wet rice cultivation). Pengurangan pada proses dan kegiatan upacara, yang semula delapan upacara daur ladang menjadi lima upacara daur sawah. Kegiatan yang profan lebih banyak pada pengembangan komoditas tanaman ekonomi di kebun-talun. Pola keruangan dalam aspek kelestarian lingkungan juga masih menempatkan posisi; gunung-pemukiman-sungai; kampung inti-kampung pengikut. Kampung yang secara geografis lebih tinggi memiliki tradisi yang lebih ketat dibandingkan dengan kampung yang lebih rendah.
\end{abstract}

Kata kunci: Kampung, komunitas, lingkungan, hutan, tradisi

\begin{abstract}
This research focused on the eternality of environment of indigenous Sunda Village of Kasepuhan Ciptagelar at Southern Halimun Mountain. The indigenous of Cengkuk Village was one compose of several cluster villages who still follow the tradition or Kasepuhan Ciptagelar in environmental management. There were internal factors and external factors led to deforestation of natural forests on average around 6-8\% per year. The growth of population which was rise up until $5.35 \%$ per year was categorized as extremely dense. With descriptive qualitative research and interview showed that Kasepuhan indigenous tradition in people at the south of the village is still practicing by protecting forestland (leuweung tutupan) only for their subsistence. Socialculture changes were occurring in the community with no agricultural activities in the forest (outer island agriculture), but agricultural activities in the field (wet rice cultivation). Reduction in process and ceremonial activities also happened, which was originally held eight ceremonial outer island agriculture rituals into five ceremonial of wet rice cultivation. More profane activities were developing economic crops in kebuntalun. The spatial pattern in environmental aspect was still having position; mountain-settlement-river; the main indigenous village of Kasepuhan — and include of several cluster villages. Indigenous villages that were geographically higher usually have more stricted tradition than the lower one.
\end{abstract}

Keywords: Kampung, community, environment, forest, tradition 


\section{BACKGROUND}

Indonesia has 10\% remain left of the world's tropical forests to support the hydrology and biodiversity. In 2010's the coverland of Java stayed 4\%. Annual deforestation is 1,3 million $\mathrm{Ha}$ $(1.2 \%)$. In the $16^{\text {th }}$ Century, natural forest in Java was still about 9 million Ha. In the late 1980's natural forest in Java only stayed 0.97 million Ha or 7\% of the total area on the island of Java (Hidayat, 2008: 88).

Kampung ${ }^{1}$ Cengkuk which is administratively located in Margalaksana Village, Cikakak, Sukabumi District, West Java, Indonesia is one of the Kampung that out of bonds and close to Halimun-Salak Mountains National Park at the section of Zone II of Halimun Mountain Cibodas Resort, Sukabumi District (Bodas Mountain Resort, 2010). Forest cover in this Kampung has a rate of deforestation an average 6-8\% per year (Yatap, 2008: 52). However the local community still practicing the tradition of Sunda Wiwitan, a sundanese tradition before Hinduism and Islam acculturated with local community beliefs which is based on respect to the ancestors for the way of life.

In the span of 20 years, from 1990 to 2010 there has been natural forest depreciation approximately $10.48 \mathrm{Ha}$ which the total area of Kampung is $1987.25 \mathrm{Ha}$, and forest ratio in 1990 decreased from $0.5 \%$ to $0.00 \%$ in 2010 (Data Profil Desa Tahun 2006). The depreciation of natural forest is closely related to population growth, affect the extension production land (rice field and garden) and other man-made environment. Kampung Cengkuk annualy population rate is $5.35 \%$ categorized very dense.

Forrest depreciation also caused the forfeit of biodiversity and one of them due to socioeconomic of local communities including demographic changes, social poverty and inequality, government policies, markets and politics role, changes in macroeconomic and social development (Wood, et al., 2000: 13). Moreover, social urbanization, landuse acreage, settlement expansion, income level, accessibility to natural resources, the values of forrest resource, education and gender equality (compiled from various sources by Yatap, 2008: 6).

\section{REASERCH METHOD}

The study formulates the values of the social environment (environmental wisdom) of Kampung Cengkuk as followers of traditions and customs of Kasepuban Ciptagelar the indigenous Sundaness communities. The research questions are:

\footnotetext{
${ }^{1}$ Kampung (English: Village) probably derived from Portuegese 'campo' means campground. In several places in Indonesia called Gampong (Aceh), Kampuang (Minang), and Kampung (Papua). Kampung is an area, where there are few houses of families lived there (rural) and opposite with the city (urban).
} 
1) What practices of traditions that stand in the context of environmental sustainability?

2) How traditions or customs that stand to changes in population, depleted of natural forests, and their subsistence activities other that in accordance with the principles of environmental sustainability by Kasepuhan customs and traditions?

The research method is qualitative with descriptive approaches. The qualitative data are text, writing, phrases, or symbol which illustrate or represent human, activities or events in social life (Neuman, 1997: 418). The qualitative research conducted for determine community perception. In addition the descriptive intended for meticulous measurement to particular social phenomena (Singarimbun and Effendi, 1989:4). The descriptive carried out to notice completely phenomenan that occur in Cengkuk traditional kampong. The collection of data obtained from the literatures, surveys, observations, participants, and in-depth interviews. Interview method used is structured interview. Data processing is done after data collected and analyzed then it's generalize the findings. The interpretations is done by drawing conclusions from the patterns that visible in integrated data which explain the phenomenon in the context of environmental preservation.

\section{CONCEPTUAL FRAMEWORK}

\section{Literatures Review}

The development and environmental issues can be seen in a unity (Salim, 1997); the unitary relationship between the natural environment, social environment and man-made environment. One of the issues in the context of social Indonesia which has an area of tropical rain forest and rural studies in the worlds second largest is the environmental degradation surrounding area of the forest due to population pressures and economic intervention.

\section{Human Ecology}

Human ecologically is an integral part their living environment. Human is formed by their environment and vice versa shaping his environment. The survival of humanity depends on the environmental integrity of his life (Soemarwoto, 2007: 35). Human through their culture, which is a tool to interact with physical and biotic environment. In every culture, there are usually elements of culture likes: language, knowledge system, social organization, systems and technology of equipment life, livelihood system, religion, and arts. The concept of environmental probalilism emphasized in this study. It is based on the the ablitily of communities with their social-culture to changes the environment. The environmental probalilism be appropriate to pre-industrial societies.

22 SOSIOGLLBAL : Jurnal Pemikiran dan Penelitian Sosiologi, Vol. 3, №. 2, Juni 2019 


\section{Rural Tourism}

In West Java region, around 12 Sundanese Kampong there are Kampung Adat Baduy, Kampung Kasepuhan, Kampung Mahmud, Kampung Cikondang, Kampung Kuta, Kampung Naga, Kampung Dukuh, Kampung Pulo, Kampung Urug, Kampung Tonggoh, Kampung Cigendang, and Kampung Palastra. Those kampongs still practicing the traditional wisdom which protecting their forest. Today those Kampongs set and promoted by local government as DTW (Daerah Tujuan Wisata or Tourism Destination Area) as a sample of sustainable development including ecotourism (Yunas, 2007) as well as rural tourism, natural tourism, and cultural tourism (Nugroho, 2011: 15). Some of the reasons why must develop the Sundanesse kampongs as tourism destinations and attraction they are living monument or heritage not dead monuments (temples, statues, etc), the same characteristics of value system and sociocultural system which is protecting the forest (leuweung), and same ecoregion in West Java covered by lowland tropical rain forest which has rich biodiversity.

\section{Forest and Communities}

The function of forests for local communities of indigenous Sunda villages have significance meaning in subsistence activities. Forest for Sundanese called leuweung; have types and utilization patterns were different in every villages and region. For example, in the village of Kampung Baduy, Ciboleger, South Banten have old forest/primary forest located in hilltop every village. Whereas, secondary forest located on a ridge or slope between hillside and hilltop (Permana, 2006: 62). The utilization of forest of indigenous village is closely related to subsistence. Community rely on forest products. Baduy community use forest for shifting cultivation, which divided into three forests; primary forests (leuweung kolot), village/kampong forest (leuweung lembur) and intensive cultivation forest (buma) (Iskandar, 1992 in Fawnia, et al., 2004: 2). As well as the indigenous community of Kasepuhan in Sukabumi District divided the forests into three, namely old-forest (leuweung kolot), secondary forest (leuweung tutupan), and intensive cultivation forest (buma or leuweung sampalan).

The pattern of Kasepuhan Kampongs nearby forest typically associated with eco-religion of rice. Hill or mountain is a place that has very important meaning. There is a linkage between the mountains with local belief that the spirits dwell in the mountain. Sacred values of the mountain are also still practiced by the traditional Sundaness Kampong. In the Kampong usually borders the sacred places or ancestor as protector of the Kampong and surrounded by flowing river as symbol of fertility. The orientation of Kampong also refers to the sunrise- 
Ary Sulistyo

sunset direction. Beside the relationship between the layout of the houses and barns (lenit) which has west-east direction (Wessing, 2003:521-523).

Indigenous communities or indigenous peoples are a community who their ancestors as beginner, stay in particular, used local resources as livelihood. They united by similarities of their descendents, history, customs, language, law, lifestyle inherited from the the wisdom of their ancestors (ILO Convention No. 169, June $27^{\text {th }}$ 1989, on Indigenous Peoples and Indigenous Community).

The Kasepuhan tradional Kampong of Cengkuk value systems still follow the conception of covering forest (or secondary forest) in the form of unwritten customary rules (pikukub) of the forest landuse practices. The processes and practical activities are sacred ceremonies of agricultural cycle which symbolizing the fertitlity (the Goddess of Dewi Sri/ Nyi Pohaci) related directly with conservation of forest landuse. In addition, there also profane activities which directly conserve the forests with add surplus value of forest landuse for homegarden (kebun talun).

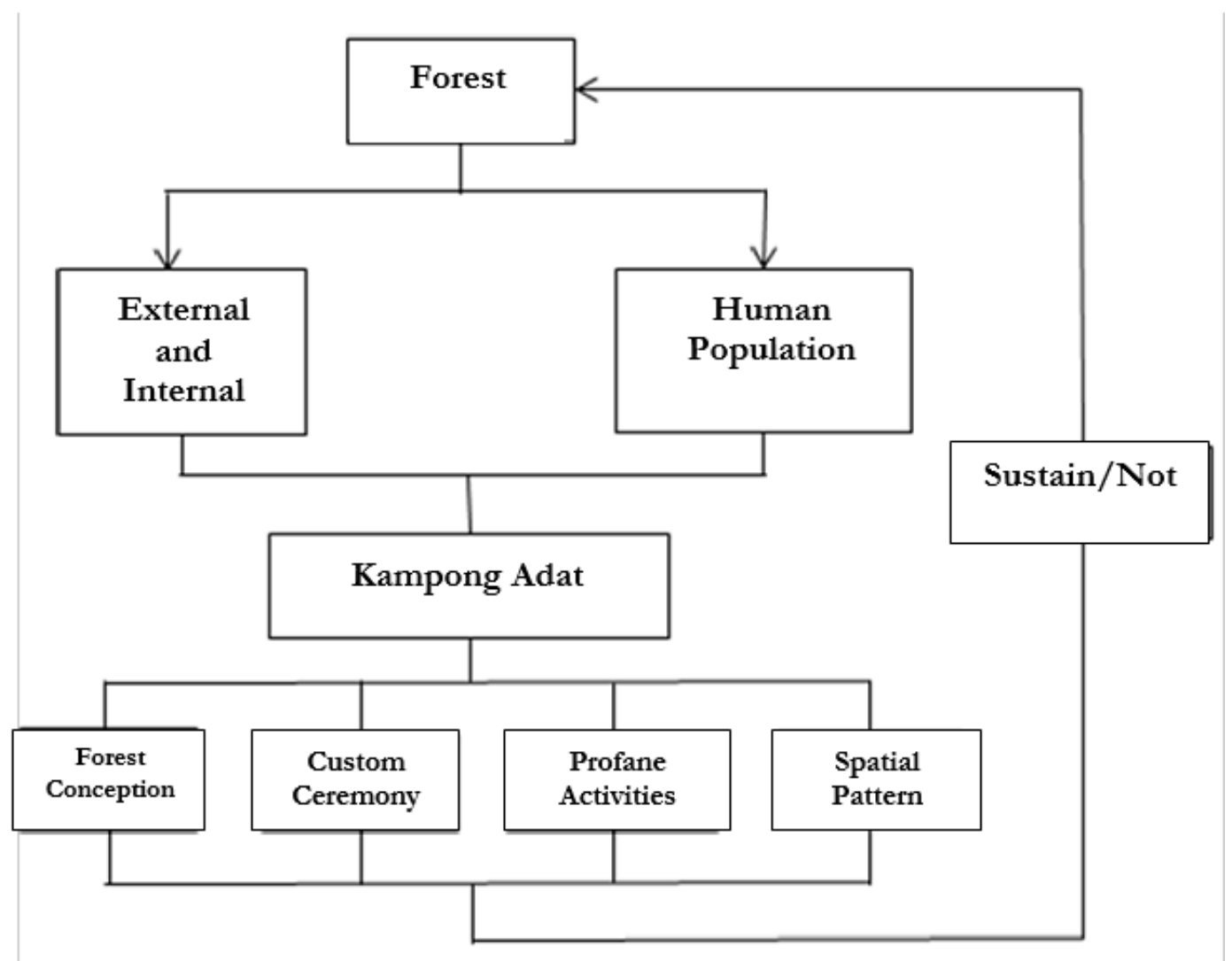

Figure 3. Research's Conseptual Framework

24 SOSIOGLIBAL : Jurnal Pemikiran dan Penelitian Sosiologi, Vol. 3, №. Z, Juni 2019 
Local Community And Its Existence: The Enviranmental Wisdom Of Kasepuhan Community....

\section{DISCUSSION}

\section{The history of Kasepuhan's Community}

The Kasepuhan communities currently dispersed in the area of South Banten, Bogor, Sukabumi, and Lebak. More than 500 years ago, the traditional community as the last descendent of Sundanese Hindu Kingdom in West Java, which centered in Pajajaran, Bogor. They lived now in the region of Halimun-Salak Mountains National Park. They fled to the mountainous area to avoid the assault troops of Banten Kingdom (Islam Kingdom). Although they are dispersed, they still follow the same customs which is reffered to as "Kesatuan Banten Kidul" or "South Banten Unity" or "Kasepuhan" which is oriented in the direction of "Kampong Gede" as community center namely Kampong Ciptarasa and Kampong Citagelar. The community customs (adat istiadat) generation by generation tradisionally led by "Abah" or "Father" in relationship that is patron-client or paternalistic (Adimihardja, 1992 in Nugraheni and Winata, 2002: 11).

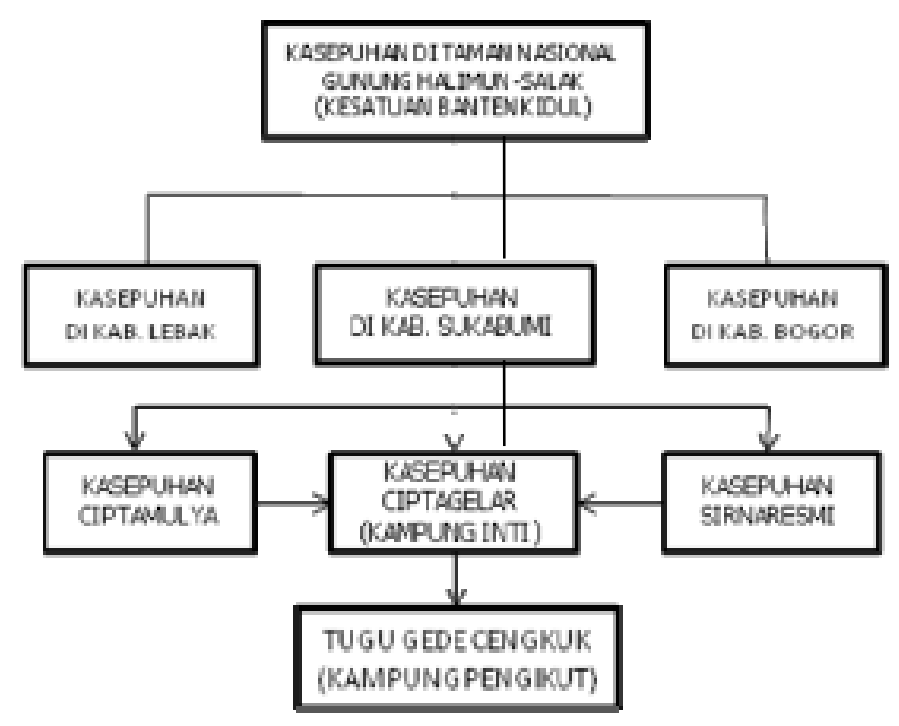

Figue 4. Structure of Adat Kasepuhan Banten Kidul

In general, the Kasepuhan communities and Kampong Cengkuk notably are Moslem, but they still practiced the traditions of their ancestors (kokolot) of Sunda Wiwitan. Sunda Wiwitan or Urang Girang or Kolot is the teaching (pikukuh) which states that the living place need to be properly maintened by communities due to it was centre of the earth or center of universe which made prosperity. The Sundanese communities or groups like this based on cultural system and social structures as well as Old Sundanese, long before Hinduism culture came and influenced to West Java or in prehistoric time (Garna, 2008: 79). 
Ary Sulistyo

\section{Environmental Setting}

\section{Geographical location}

Kampung Cengkuk is geographically located at an altitude 382-415 meters above sea level and astronomically $6^{\circ} 53^{\prime}$ South Latitude and 108 $28^{\prime}$ East Longitude. Kampong Cengkuk administratively located at Margalaksana Village, Cikakak Subdistrict, Sukabumi District, West Java Province.

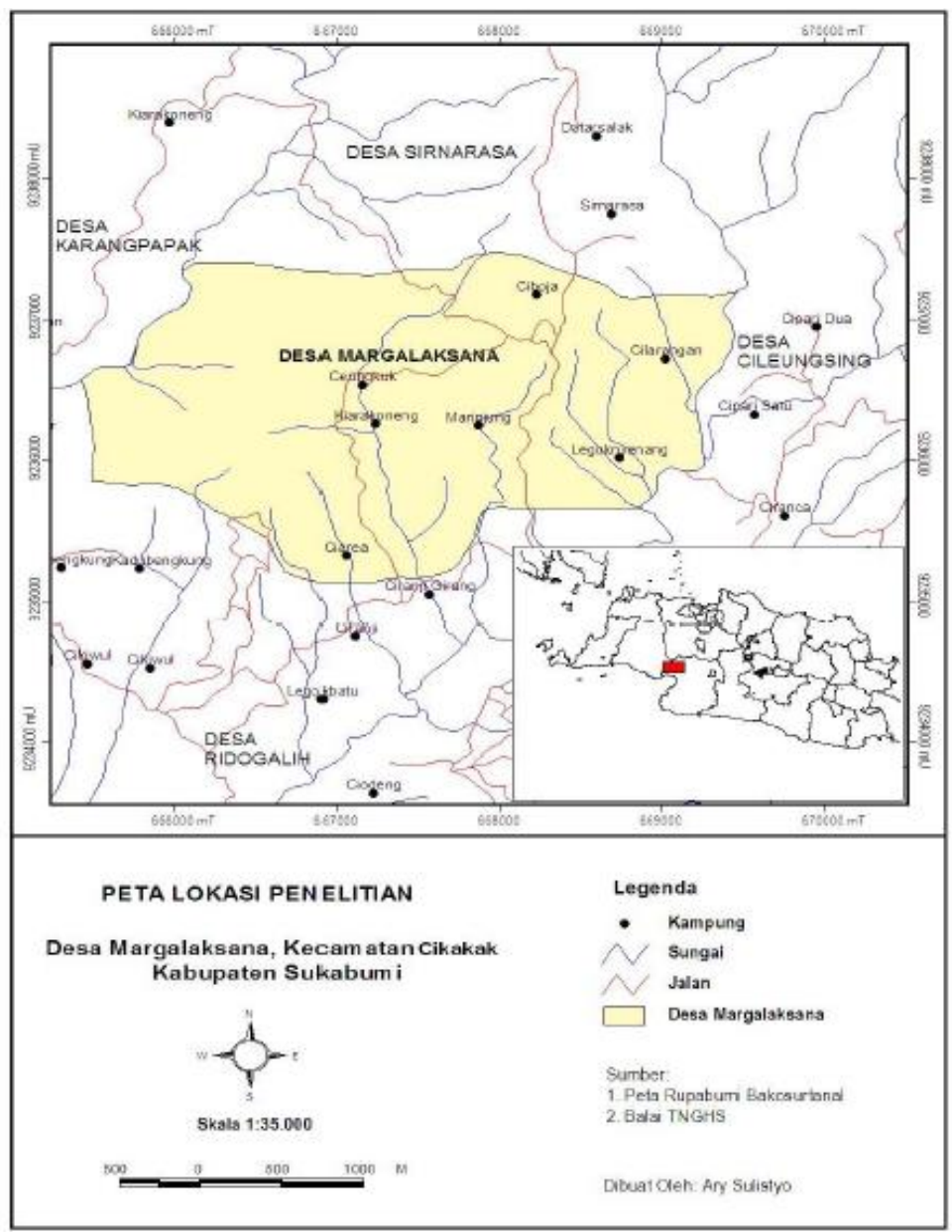

Figure 5. Map of Margalaksana Village and Kampong Cengkuk

\section{Geology}

According to Van Bemmelen (1970), the physiographic region included in series of southern mountains of West Java. This region is a volcanic hills with declitivous slope and elevation between 500-700 meters above sea level.

\section{Climate}

According to Schmidt and Ferguson, the area of Bodas Mountain Resort has climate type B with the ratio of the number of avarege months of dry and wet (Q) is 24.7 and monthly

26 SOSIOGLUBAL : Jurnal Pemikiran dan Penelitian Sosiologi, Vol. 3, №. 2, Juni 2019 
average temperature $31.8^{\circ} \mathrm{C}$ (minimum $19.7^{\circ} \mathrm{C}$ and maximum $33^{\circ} \mathrm{C}$ ). The average humidity is $88 \%$ with the average rainfall is $4.000-6.000 \mathrm{~mm} /$ year (Resort Gunung Bodas, 2010).

\section{Water Sources}

The watershed is an area of land that is bounded by topographic ridges mountain accommodate and store the water for later distribute to the sea through the main river (Asdak, 2004: 1-4). In Kampong Cengkuk and surrounding there are three springs flow across the Kampong toward Cimaja River and Cisukawanyana River until Pelabuhan Ratu estuary.

\section{Community perception}

The communities occupation beside in agriculture sector, there are closely linked to agriculture (off-farm) and apart from agriculture (non-farm). Based on the surveys of 50 household with purposive sampling method obtained information that the average of the residents (98\%) is off-farm occupation and average income USD 25 per month (in 2009). The tota area of Kampong is 12.5 hectars with land ratio 0.07 hectars every household. The community perception of forestland at Batu Lawang area $47.95 \%$ for sources of food security (homegarden) and cultivated land and $46.93 \%$ said that forest used as water springs for wet rice cultivation

\section{The practices of traditional environmental preservation}

The practices of traditional environmental preservation consist of sacred activities and profane activities. In the Kampong of Cengkuk, a sacred activities include the activities conducting religious aspects in the practice of forest and water sources stewardship (subsistence), particularly in regard to agriculture recycling ceremony (according to calendar calculations) and profane activities include the activities to carry out daily for forest and water resources management practices (surplus value). At customary community of Kampong Cengkuk, the agricultural recycling ceremony not conducted anymore, except in some main Kampongs such as Ciptagelar, Sirnarasa, and Ciptamulya.

Shifting cultivation pattern (outer island agriculture, term in cultivation practices in Indonesia, see Geerts, 1963) in Kampong Cengkuk generally has turned into non-irrigated rice cultivation (wet rice cultivation, term in the practice of rice cultivation in Indonesia, see Geertz 1963) that mix with homegarden (kebun talun).

\section{Seren Taun Annual Ceremony}

Seren Taun ceremony is the largest annual ceremony that is organized by Kasepuhan communities. The seren taun ceremony was conducted at the end of harvesting period. The ceremony was held to tribute Nyi Pohaci or Goddess of Sri who is a protective symbol of 
agriculture in Java. In the peak of harvesting (usually every August), the communities came to the center communities of Ciptagelar. They brought kind of 2 bunches of rice (gedeng) to be put into the rice community barns (leuit si jimat) at the peak of ceremony.

\section{Profane Activities of Forest Management}

Profane activities means customary activities that are ordinary or not sacred activities. The activities that come from the communities based on the awareness of the importance of forest and water sources. The activities may include planting trees on homegarden (kebun talun) in addition to the subsistence. This activities is intended as addition food but also meet the surplus value. Basically, profane kampongs are more open to changes and abonding related traditions with subsistence (ceremonies related to agricultural cycle) even the official religion is Islam. Kebun talun is a form of cultivation system that resembles in homegarden, but generally in outside of the Kampongs and mostly annual crops. The homegarden itself identified as the landuse system around homes and generaly planted various types of plants and poultry and fishes. And upland (tegalan) generally used for cultivation of cassava, banana, and other types of plants especially to meet need of household consumption itself (Soemarwoto, 1983 in Suhardjito, 2002: 184).

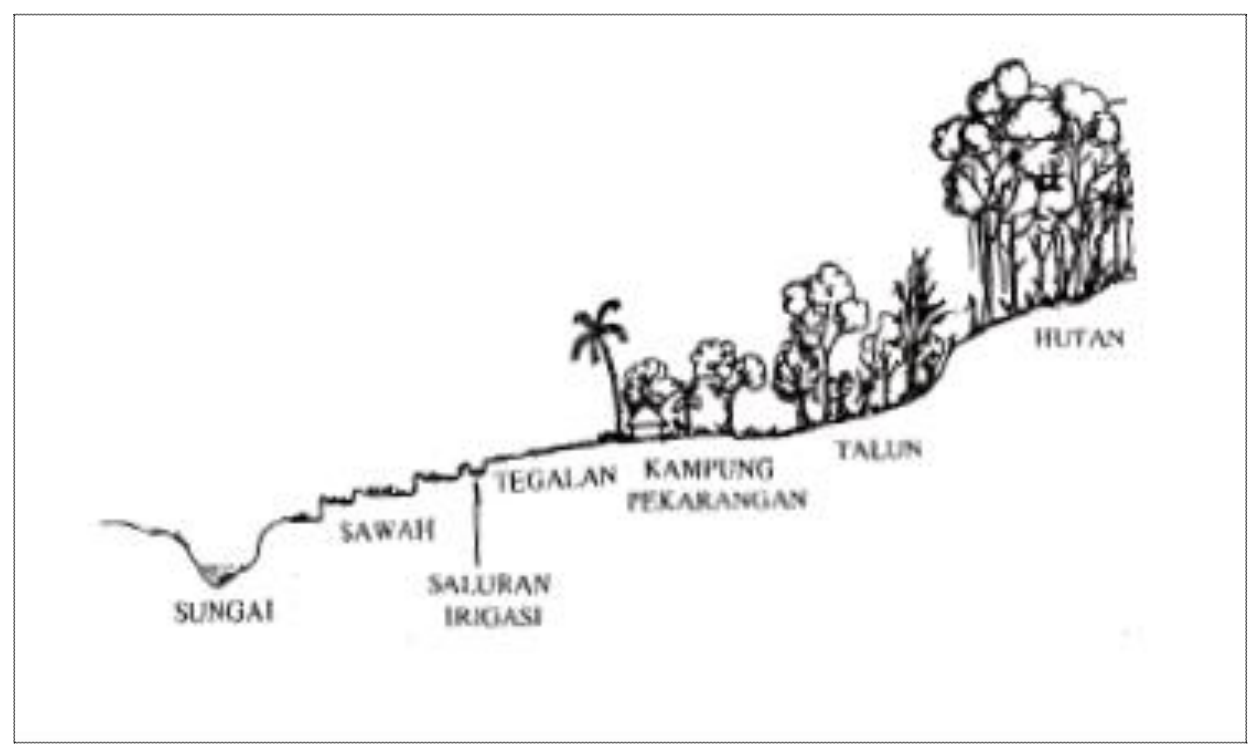

Figure 6. Cross-Section Landuse of the Kampong

Based on observation in 2006, mostly food crops and commodities planted in Margalaksana Villlage and Kampong Cengkuk are banana and rice. Paddy rice basically can not be traded just for family consumption.

28 SOSIOGLUBAL : Jurnal Pemikiran dan Penelitian Sasiologi, Vol. 3, №. 2, Juni 2019 


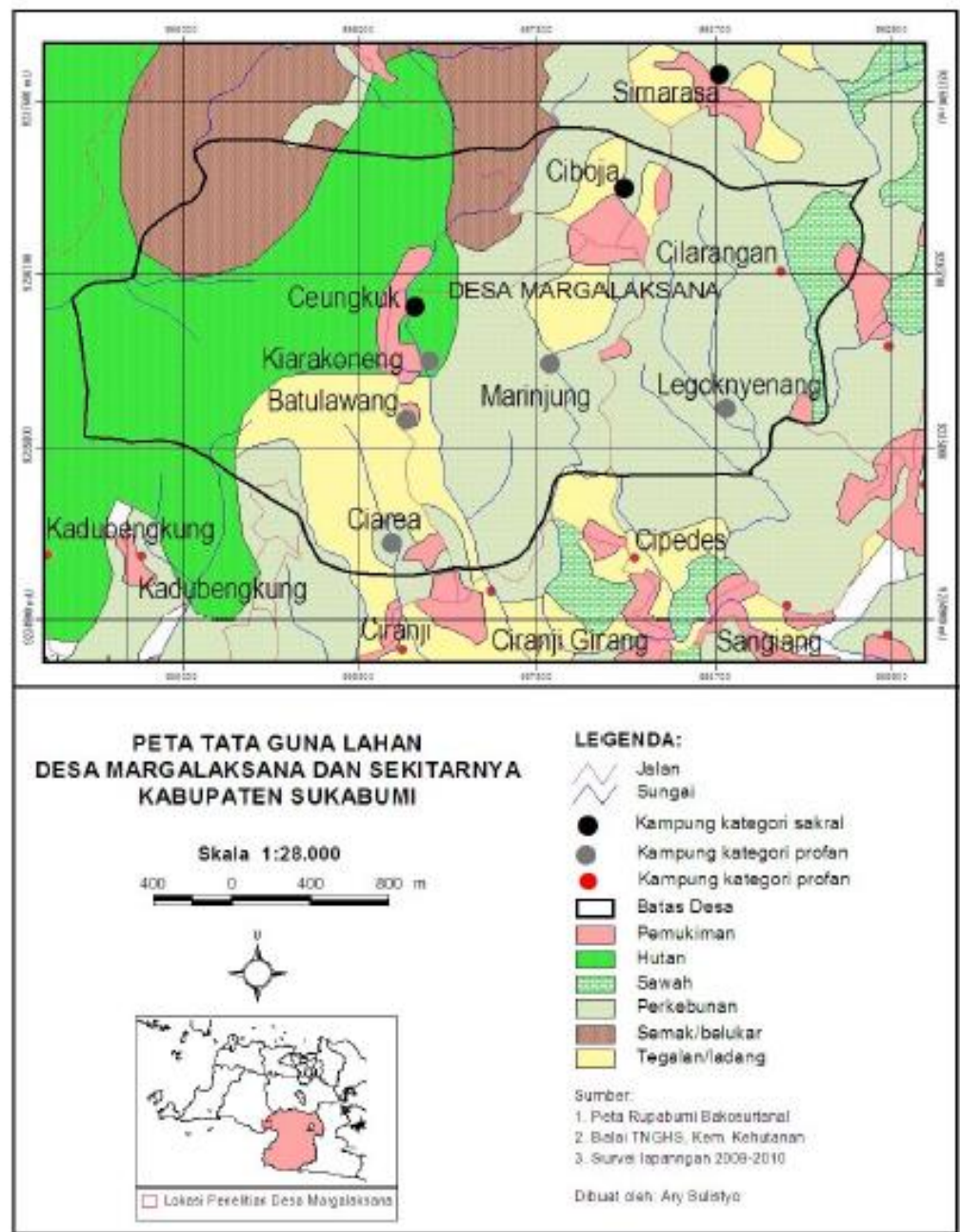

Figure 7. Map of Landuse of Cengkuk Local Community (Kampung), Sukabumi District, West Java

\section{The Impact of Forest Depletion and Population Pressure}

The communities' adjustment (internal factors) to the depletion of the forest area and the population pressure is that there has been changes the orientation of the subsistence pattern form outer island agriculture into wet-rice cultivation. Changes depend on the extent of physical occupation (hill side and other residential areas) in the lower of hills/forests. Reduced conception in forest cultivation ceremonies that originally existed only three (3), one of them in secondary forest (leuweung tutupan) due to maintenance aspects of subsistence.

In the Kampong Cengkuk there is only a rice cycing ceremonies only. As results of subsistence changes in wet rice cultivation practices in forestland. The changes is caused the residents in the Kampong already developing economic commodities crops (especially food and produced in homegarden/kebun-talun) as supporting subsistence of economic valuable. The external factors affects communities leaving the customs and influence on the physical changes of the village, such as housing constructions (from house of stilt to land house). 


\section{Acknowledgement}

I would like to thanks to Dr. Boedhihartono from Department of Anthropology and also as Senior Lecturer at Vocational School of Tourim at University of Indonesia for sharing valuable knowledge as my mentor, teacher, friend, and father to me. It's truly honor for me, although my undergraduate background from archaeology which is deal with material culture, but he patiently guided me with his good scientific approches in anthropology and how to look community as unity in culture.

\section{REFERENCES}

Adimihardja, K., 2001. "Kearifan Lokal Komunitas Adat Mengelola Sumber Daya Agraria: 75-85," in Jurnal Analisis Sosial. Akatiga, Bandung.

Adimihardja, K., 2002. "Upacara Daur Pertanian," in Indonesia Heritage 2: Manusia dan Lingkungan; 110_111. Buku Antar Bangsa, Jakarta (Bahasa Indonesia Edition ).

Adimihardja, K., 2009. "Leuweung Titipan: Hutan Keramat Warga Kasepuhan di Gunung Halimun," in Situs Keramat Alami: Peran Budaya dalam Konservasi Keanekaragaman Hayati: 78-82. H. Soejito, Y. Purwanto dan E. Sukara (ed.). Yayasan Obor Indonesia, Jakarta.

Asdak, C., 2004. Hidrologi dan Pengelolaan Daerah Aliran Sungai. Gadjah Mada University Press, Yogyakarta.

Balai Taman Nasional Gunung Halimun Salak, 2007. Above Ground Carbon Estimation of

Bungin, B., (ed.), 2008. Metode Penelitian Kualitatif: Aktualisasi Metodologis ke Arah Ragam Varian Kontemporer. Raja Grafindo Persada, Jakarta.

Ekadjati, E.S., 1995. Kebudayaan Sunda: Suatu Pendekatan Sejarah. Dunia Pustaka Jaya, Jakarta.

Galudra, G., 2003. Conservation Policies versus reality: case study of floral, fauna, dan land utilization by local communities in Gunung Halimun-Salak National park, dalam Laporan Penelitian World Agroforestry Centre (ICRAF Southeast Asia) No.2003_4, Bogor.

Garna, J.K., 2008. Budaya Sunda: Melintas Waktu Menantang Masa Depan. Lembaga Penelitian Unpad and Judistira Garna Foundation, Bandung.

Geertz, C., 1963. Agricultural Involution: The Processes of Ecological Change In Indonesia. University of California Press, Berkeley.

Gunung Halimun Salak National Park: Potential Economic Value for Carbon Trading under Avoiding Deforestation Scheme. Laporan Penelitian, Sukabumi.

Hardesty, D.L., 1977. Ecological Anthropology. John Willey \& Sons, New York.

Harsojo, 1979. "Kebudayaan Sunda," dalam Manusia dan Kebudayaan di Indonesia, Koentjraningrat (ed.) Manusia dan Kebudayaan; 300_320. Djambatan, Jakarta (Fourth Edition).

Hartono, et al., 2007. Taman Nasional Gunung Halimun-Salak: Menyingkap Kabut Gunung Halimun Salak. Gunung Halimun-Salak National Park Management Project, Bogor.

Hidayat, H., 2008. Politik Lingkungan: Pengelolaan Hutan Masa Orde Baru dan Reformasi. Yayasan Obor Indonesia, Jakarta.

Irwanto, 2006. "Dinamika dan Pertumbuhan Hutan Sekunder" dalam http://www.freewebs.com/irwantoshut/hutan_sekunder.pdf. diakses tanggal $11 / 12 / 2010$.

Keputusan Menteri Dalam Negeri No.25 Tahun 1996 Tentang Data Dasar Profil Desa/Kelurahan

Keputusan Presiden No.32 Tahun 1990 Tentang Pengelolaan Kawasan Lindung

30 SOSIOGLUBAL : Jurnal Pemikiran dan Penelitian Sasiolagi, Vol. 3, №. 2, Juni 2019 
Local Community And Its Existence: The Enviranmental Wisdam Of Kasepuhan Community....

Koentjaraningrat, 2002. Pengantar Teori Antropologi. Rineka Cipta (cetakan kedelapan), Jakarta.

Laporan Perkembangan Pencapaian Tujuan Pembangunan Milenium Indonesia Tahun2004. http://www.targetmdgs.org/download/MDG_Report_2008_En.pdf, di akses tanggal $11 / 12 / 2010$.

Marzali, A., 2003. Strategi Peisan Cikalong Dalam Menghadapi Kemiskinan. Yayasan Obor Indonesia, Jakarta.

Mundardjito, 2006. "Lingkungan Alam dan Sosial Dalam Perspektif Sejarah," dalam Rapat Penyusunan Pedoman Kajian Geografi Sejarah, 7-8 April 2006, Di Cibogo, Bogor.

Mundardjito, 2008. Materi Kuliah Pemukiman Program Studi Arkeologi Fakultas Ilmu Budaya Universitas Indonesia, Jakarta.

Neuman, W.L., 1997. Social Research Method: Qualitative and Quantitative Approaches. Allyn and Bacon, Boston (edisi ketiga).

Nugraheni, E., dan A. Winata, 2002. Kearifan Tradisional Masyarakat Kasepuhan Halimun Ditinjau dari Aspek Kelestarian Lingkungan. Laporan Penelitian Pusat Studi Indonesia Universitas Terbuka, Jakarta.

Nugroho, I., 2011. Ekowisata dan Pembangunan Berkelanjutan. Yogyakarta: Pustaka Pelajar.

Odum, E. P., 1983. Basic Ecology. Saunders College Publishing, Philadelphia.

Peluso, N.L., 2006. Hutan Kaya, Rakyat Melarat: Penguasaan Sumber Daya dan Perlawanan di Jawa. Konphalindo, Jakarta.

Permana, R.C.E., 2006. Tata Ruang Masyarakat Baduy. Wedatama Widya Sastra,Jakarta.

Poerwanto, H., 2008. Kebudayaan dan Lingkungan: Dalam Perspektif Antropologi. Pustaka Pelajar, Yogyakarta (fourth edition).

Purba, J., (ed.), 2002. Bunga Rampai Kearifan Lingkungan. Kementrian Negara Lingkungan Hidup, Jakarta.

Purba, J., (ed.), 2005. Pengelolaan Lingkungan Sosial. Yayasan Obor Indonesia, Jakarta.

Rambo, T., 1983."'Conceptual Approaches to Human Ecology," in East West Environment and Policy Research Report No. 14. East-West Environment and Policy Institute, Hawaii.

Resor Gunung Bodas, 2010. Laporan Survei Potensi Resor Gunung Bodas. Seksi Pengelolaan Wilayah III, Balai Taman Nasional Gunung Halimun Salak, Sukabumi.

Resossoedarmo et. al., 1985. Pengantar Ekologi. Remaja Karya, Bandung.

Salim, E., 1997. "Pembangunan Berkelanjutan," in Widjojo Nitisastro 70 Tabun: Teori, Kebijaksanaan, dan Pelaksanaan II: 921-931. M. A. Anwar, A. Ananta, dan A. Kuncoro (ed.). Fakultas Ekonomi Universitas Indonesia, Jakarta.

Salura, P., 2007. Menelusuri Arsitektur Masyarakat Sunda: Ciptasastrasalura, Bandung.

Singarimbun, M. dan S. Effendi (ed.), 1989. Metode Penelitian Survai. Lembaga Penelitian, Pendidikan dan Penerangan Ekonomi dan Sosial, Jakarta (revision edition).

Sodikin, 2006., Kearifan Lingkungan pada Masyarakat Baduy: Faktor-Faktor yang Mempengaruhi Pelestarian Fungsi Lingkungan dan Perubahannya Di Kabupaten Lebak, Banten. Tesis Pascasarjana S2 Kajian Ilmu Lingkungan UI, Jakarta.

Soemarwoto, O., 2004. Ekologi, Lingkungan Hidup dan Pembangunan. Djambatan, Jakarta (Tenth edition).

Soemarwoto, O., 2007. Analisis Mengenai Dampak Lingkungan. Gadjah Mada University Press, Yogyakarta (Twelveth edition).

Soerjani, et al., 1987. Lingkungan, Sumberdaya Alam dan Kependudukan dalam Pembangunan. UI Press, Jakarta. 
Soerjani, M., A. Yuwono, dan D. Fardiaz. 2006. Lingkungan Hidup: Pendidikan, Pengelolaan Lingkungan, dan Pembangunan Berkelanjutan. Institut Pendidikan dan Pengembangan Lingkungan, Jakarta.

Stenger, et al., 2009. "Valuing Environmental Good and Services Derived from the Forest," in Journal of Forest Economics, 15: 1--14.

Sudarti, et al., 2005., Ekskavasi Penelitian Situs Tugu Gede Cengkuk, Desa Margalaksana, Kecamatan Cikakak, Kabupaten Sukabumi, Propinsi Jawa Barat. Laporan Hasil Penelitian Arkeologi. Dinas Pendidikan dan Kebudayaan, Sukabumi.

Suharjito, D., 2002. Kebun Talun: Strategi Adaptasi Sosial Kultural dan Ekologi Masyarakat Pertanian Lahan Kering Di Desa Buniwangi, Sukabumi, Jawa Barat. Disertasi S3 Program Pascasarjana Program Studi Antropologi Universitas Indonesia, Jakarta (tidak diterbitkan).

Sukendar, H., 1993. Arca Menhir Di Indonesia: Fungsinya dalam Peribadatan. Disertasi S3 Program Pascasarjana Program Studi Arkeologi Universitas Indonesia, Jakarta (tidak diterbitkan).

Supriyanto et al., 2009. Laporan Akhir Proyek Pengelolaan Taman Nasional Gunung Halimun Salak Pebruari 2004-2009. Taman Nasional Gunung Halimun Salak, Gunung Halimun Salak National Park Managemnet Project, Departemen Kehutanan dan JICA, Jakarta.

Supriyanto, B., 2008. "Memintal Kohesi Sosial Halimun Salak," dalam National Geographic, :76-79. Edition of June 2008. Gramedia Percetakan, Jakarta.

Surjadi, A., 1974. Masyarakat Sunda: Budaya dan Problema. Alumni, Bandung.

Undang-undang No. 26 Tahun 2007 Tentang Penataan Ruang

Undang-Undang No. 41 Tahun 1999 Tentang Kehutanan

Undang-Undang No. 5 Tahun 1960 Tentang Peraturan Dasar Pokok-Pokok Agraria

Undang-Undang No. 5 tahun 1990 tentang Konservasi Sumberdaya Alam Hayati dan Ekosistemnya

Undang-Undang No.32 Tahun 2009 Tentang Perlindungan dan Pengelolaan Lingkungan Hidup

Utomo, E.P. et al., 2003. Zona Bencana Geologi Jawa Barat. Laporan Akhir Studi Kebijakan IPTEK, Pusat Penelitian Geoteknologi, Bandung.

Van Bemmelen, 1970. The Geology of Indonesia and Adjacent Archipelagoes Vol. 1A. The Hague Government Printing Office.

Warnean, S., 1988. "Pandangan Hidup Orang Sunda: Satu Hasil Studi Awal," in Masyarakat dan Kebudayaan: Kumpulan Karangan untuk Prof. Dr. Selo Someardjan: 399-419. Djambatan, Jakarta.

Wessing, R., 2003. "The Shape of Home Spatial Ordering in Sundanesse Kampung," in Indonesian House: Tradition and transformation in vernacular architecture. R. Schefold, P.J.M. Nas dan G. Domenig (ed.). Koninklijk Instituut voor Taal-, Land- en Volkendunde (KITLV), Leiden.

Whitten, T., et al., 1999. "Ekologi Jawa dan Bali," in Ekologi Indonesia II. Prenhallindo, Jakarta.

Wood, A, P. et al., (ed.), 2000. The Root Causes of Biodiversity Loss. Earthscan Publication, London.

Yatap, H., 2008. Pengaruh Peubah Sosial Ekonomi Terhadap Perubahan Penggunaan dan Penutupan Lahan di Taman Nasional Gunung Halimun Salak. Tesis Program Studi Ilmu Pengetahuan Kehutanan. Sekolah Pascasarjana Institut Pertanian Bogor, Bogor.

32 SLSIOGLLBAL : Jurnal Pemikiran dan Penelitian Sosiologi, Vol. 3, No. 2, Juni 2019 
Yunaz, H., 2007. Pola Pengembangan Ekowisata Berkelanjutan: Studi Kasus Taman Nasional Gunung Gede Pangrango, Propinsi Jawa Barat. Disertasi Doktor Program Studi Ilmu Lingkungan Universitas Indonesia

Zaimah, 2007. Kearifan Lingkungan Masyarakat Kampung Kuta Bagi Pelestarian SDA dan Lingkungan (Studi Kasus Desa Karangpanigal Kecamatan Tambaksari, Ciamis). Tesis Pascasarjana S2 Kajian Ilmu Lingkungan UI, Jakarta.

\section{Maps}

Peta Rupabumi Dijital Indonesia Lembar Pelabuhan Ratu Skala 1:25.000. Bogor: Badan Survey dan Pemetaan Nasional.

Peta Tematik Taman Nasional Gunung Halimun, Wilayah Seksi Pengelolaan III, Resor Gunung Bodas, Sukabumi Tahun 2010.

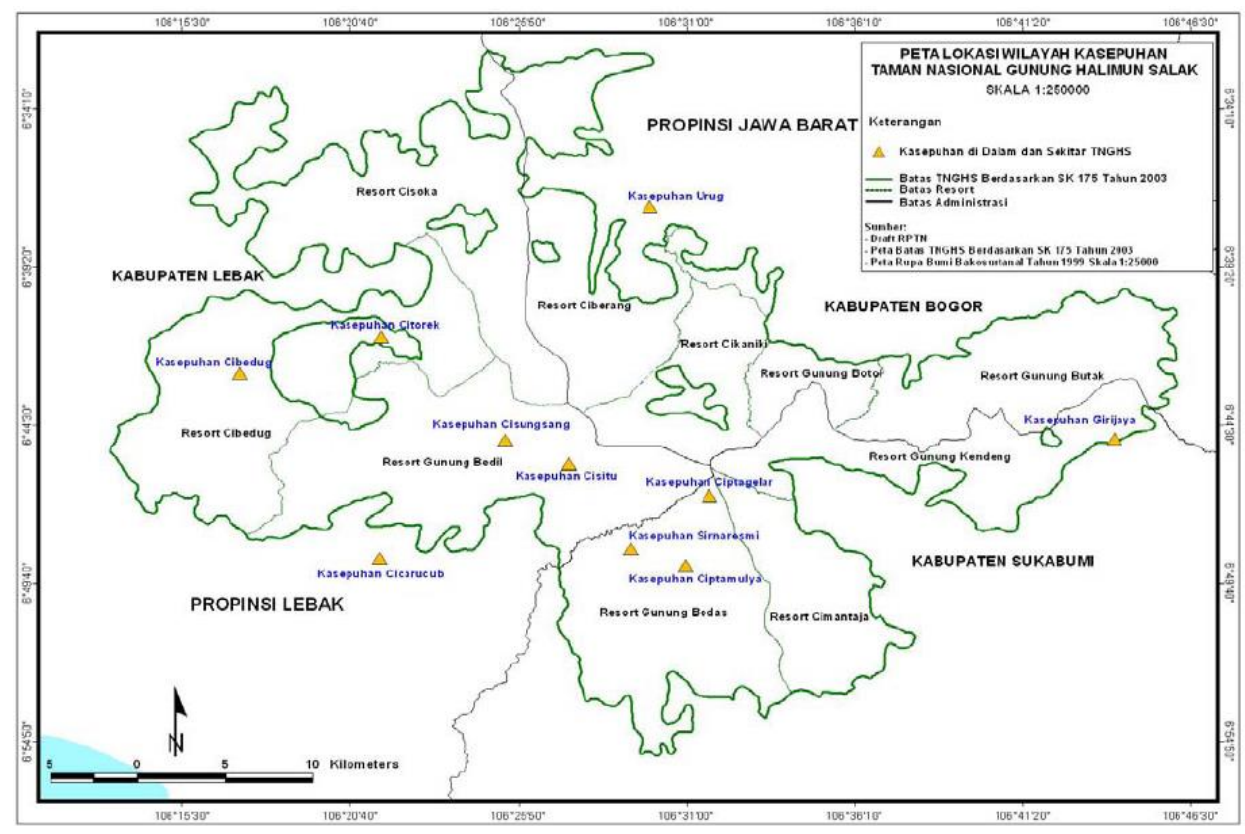

\section{Photos}

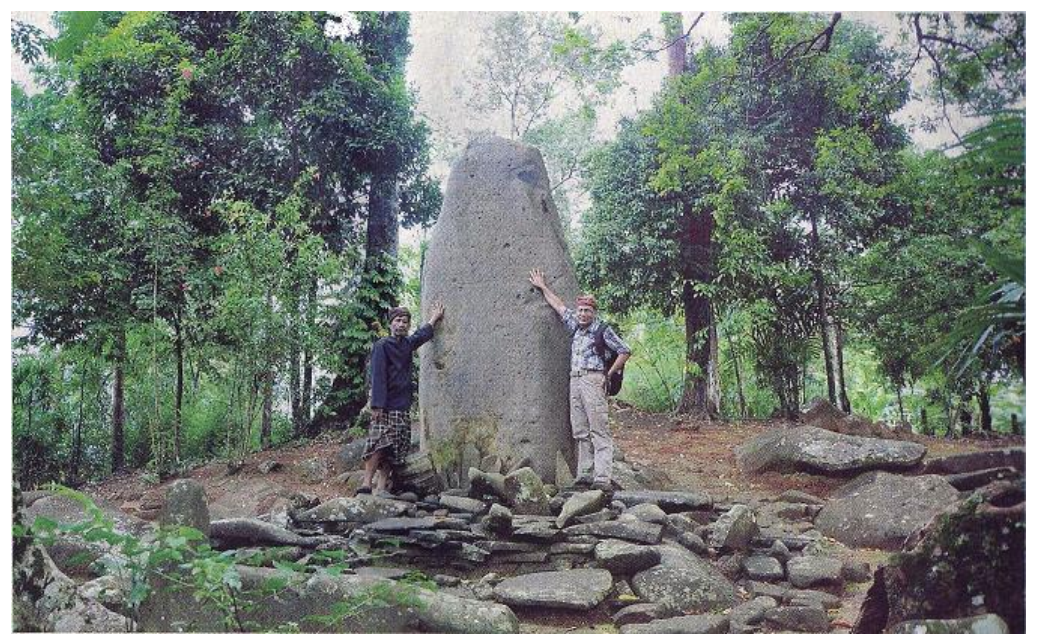

The Archaeological Site of 'Megalith Culture' at Kampung Cengkuk as tourism attractions 
Ary Sulistyo

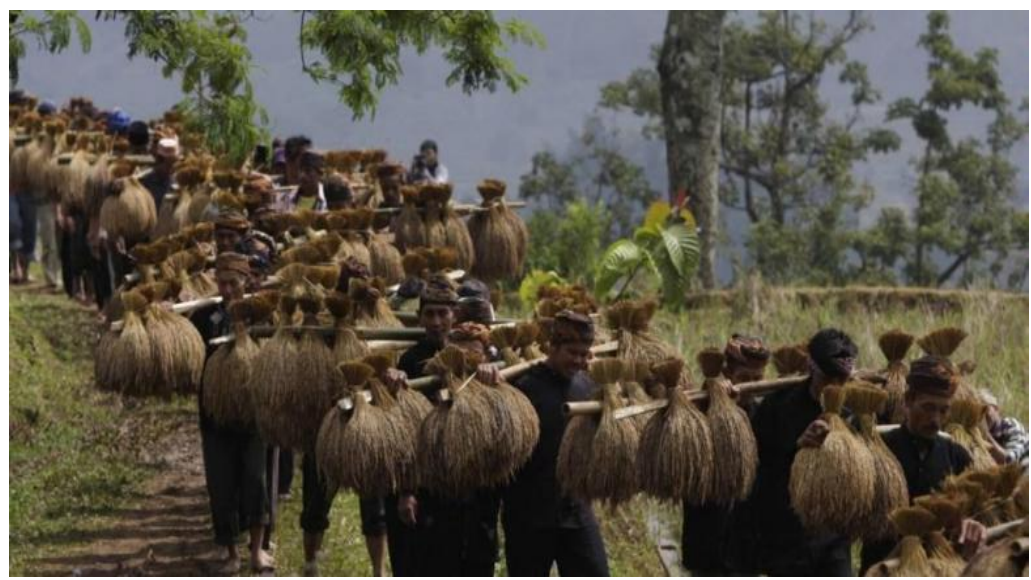

The Annual Seren Taun's Ritual Gift to Mother-Earth (Dewi Sri) followed by Local Communities and gathering at the Centre of 'Kampung' Gede Kasepuhan Ciptagelar

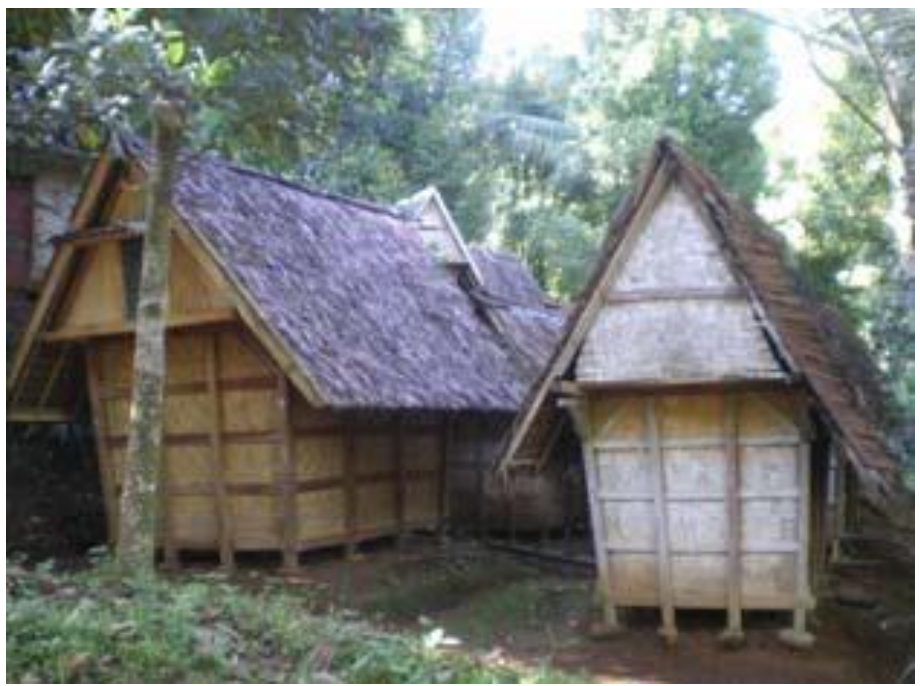

Rice Paddy Stockpile (Lenit) Kampong Cengkuk

34 SDSIOGLOBAL : Jurnal Pemikiran dan Penelitian Sosiologi, Vol. 3, №. 2, Juni 2019 